\title{
In Search of Pedagogies for Teaching Qualitative Research Online: A Vygotskian Approach
}

\author{
Maja Miskovic $^{1} \&$ Elena Lyutykh ${ }^{1}$ \\ ${ }^{1}$ College of Graduate Studies, Concordia University, Chicago, United States \\ Correspondence: Maja Miskovic, College of Graduate Studies, Concordia University, 7400 Augusta St., River Forest, \\ IL 60305, United States. Tel: 1-708-209-3554.
}

Received: July 12, 2017

Accepted: August 1, 2017

Online Published: September 19, 2017

doi:10.5430/irhe.v2n3p60

URL: https://doi.org/10.5430/irhe.v2n3p60

\begin{abstract}
Little has been said on how to teach qualitative research in general and more recently on how to do so in online courses. Drawing on the cultural-historical theory of Lev Vygotsky and his followers, we engage with theoretical tenets that inform a design of an online qualitative research course in a private liberal arts university in the United States with large enrollments of doctoral students in leadership studies. Through examination of constructivist approaches to online education that are integrated within our classroom practices, we highlight unique challenges of teaching qualitative research online and offer insights to inform instructors of similar courses with intent to continue an important conversation about complexities of teaching qualitative research.
\end{abstract}

Keywords: online teaching, qualitative research, doctoral studies, Vygotsky

\section{Introduction}

This paper emerges from the institutional shift we are part of in offering doctoral-level classes in qualitative and other research methods completely online in 8-week terms. Our initial resistance to the online mode of teaching has given way to molding our presence and forming our voices in the asynchronous classrooms where we are given short time to address the goals neatly stated in the course syllabus, with many of them merely touching the surface. This particular conjunction makes us question our teacher's identity as we contemplate Morrison-Saunders and Hobson's (2013) heed to the university teachers to "help bring into being the values of a higher education" (p. 212). We are nested in a university that places an utmost value on teaching, but also awards doctoral degrees in educational leadership. Most of our students work in schools, where the data driven decision making language rules the day, where "inquiry is cut off from politics," where "biography and history recede into the background," and where "technological rationality prevails" (Denzin \& Lincoln, 2013a, p. 3). We have experienced over the years an increased emphasis on the instrumental and pragmatic nature of not only the courses we teach but also of the entire programs' philosophies and purposes. To this we would add a dissociation of the scholarly and the professional, as our students bring to the classroom an acute sense of what should be done in order to be valued in their professional world, accompanied with ideas of what could/should be done as research. Working with and within this forced dichotomy, teaching qualitative research sometimes seems like a luxury, an intellectual and aesthetic exercise confined in the space of online discussion threads.

We argue that there is a need to find ways to foster awareness of the complexities of online research contexts and relationships and how they are embedded in community, culture, language, history, and power structures. Through field research and theoretical dialogue, we want our students to learn, understand, and grapple with inherent tensions in the interplay among purpose, methodology and ethics, while cultivating a personal understanding of their relationship to the research and to the participants. How do we enact the principles of qualitative research in an environment that seems counterintuitive to this mode of inquiry? As instructors of such classes, educated in a traditional university setting, who until recently taught in face-to-face (f2f) classrooms, we engage scholarly sources and publicly available data on the trends in online education to highlight unique aspects of teaching qualitative research online. By examining four tenets based in Vygotsky's cultural-historical theory namely, scientific concepts, mediation of thinking, cognitive apprenticeship, and community of practice - we offer a theoretical insight for approaching the course design and delivery in this previously unfamiliar context. 


\section{Qualitative Research and Online Education in the United States: General Trends}

Given that qualitative research is not a monolith but an inter- and transdisciplinary field shaped by multiple ethical and political positions, a large tent that embraces different and often conflicting epistemologies (Denzin \& Lincoln, 2013b), it is easy to understand why there is little recommendation when it comes to teaching qualitative research methods online. The field of qualitative research notably defies attempts to reduce teaching the art of qualitative inquiry to a set of step-by-step strategies (Breuer \& Schreier, 2007) and online platforms seem "daunting or potentially even antithetical to the field" (Hunter, Hinderliter Ortloff, \& Winkle-Wagner, 2014, p. 2). Although there is an abundance of textbooks on how to design and conduct qualitative research (see most notable examples, with multiple editions: Creswell, 2012; Denzin \& Lincoln, 2013a, 2013b; Glesne, 2013; Marshall \& Rossman, 2016; Maxwell, 2012; Merriam, 2009) and how to collect data in online communities (Johns, Chen, \& Hall, 2004; Poynter, 2010), there are few studies on how to teach qualitative research, let alone how to go about it in an online format. For example, studies describe pedagogies of teaching qualitative research $\mathrm{f} 2 \mathrm{f}$ through different phases and application of fieldwork, methods, and techniques (Onwuegbuzie et al., 2012; Waite, 2014), teaching qualitative data analysis (Mulvihill, Swaminathan \& Bailey, 2015), or the utilization of popular media and group work in teaching Grounded Theory (Creamer, Ghoston, Drape, Ruff, \& Mukuni, 2012). In a more metacognitive and reflexive manner, Humble and Sharp (2012) described co-journaling as a mean of support in teaching, while Cox (2012) and Booker (2009) outlined an instructional approach to teaching qualitative research to school practitioners and administrators who, in their daily practice mostly think through the quantitative data. With the growing number of online courses we agree with Hunter et al. (2014), who argue that teachers of qualitative research "both traditional and distance must teach using interactive, engaging, and reflective methods" (p. 9).

It is not clear, though, how well online programs are able to meet this call despite the fact that close to $30 \%$ of graduate students or adult learners in the US are either enrolled exclusively or in some distance courses (U.S. Department of Education, 2014). Similarly, according to the survey responses collected at more than 2,800 colleges and universities in the US in 2013, over seven million or 33.5\% of students took at least one online course (Allen \& Seaman, 2014). Academic leaders view online education favorably: two-thirds believe that there would be substantial use of student-directed, self-paced components in future online courses (Allen \& Seaman, 2014), particularly given the fact that, from the higher education administrative standpoint, online education represents a cost-cutting measure responding to state budget cuts. Also, the lower personnel costs and greater scheduling flexibility associated with contingent faculty are particularly attractive to administrators (Ortagus \& Stedrak, 2013).

Online education is a mainstream rather than a trend and it will continue to shape the landscape of higher education in the US. For its supporters, it denotes flexibility, access, and affordability to many potential students (Kentnor, 2015). It also requires of students more self-reliance, self-discipline, and development of clear and concise written communication (Reese, 2015), since online discussion threads remain a permanent record of written speech. For its critics, online education, particularly the asynchronous type, is the dissociative process, where the quality of education is compromised and instructors and students are disconnected, unable to fully build a learning community (in Reese, 2015). Given this criticism and the recognition that $\mathrm{f} 2 \mathrm{f}$ pedagogy cannot be merely replicated in an online format, many researchers have turned to constructivist approaches to teaching in order to (re)develop viable teaching strategies attuned to the different learning environment.

\subsection{Constructivist Approaches to Online Education}

A search in the EBSCO host engine using the terms "constructivism" and "online education" revealed over 2,000 academic sources published in English language in the past 25 years. Given the variety of topics and methodologies that relied on different strands of constructivism, our main focus was on the studies that explicitly referred to Vygotsky's theory. We quickly learned that, "When used in contemporary pedagogical discourse, the ideas of Dewey and Vygotsky are no longer 'their' ideas. Instead they are embedded in, and thus reshaped by, a set of relations embodied within the discursive practices of constructivist pedagogies" (Popkewitz, 2001, p. 330). For us, the essence of Vygotsky's writings lies in the notion of historical-dialectical interdependency between the individual and the social. Although his theory has been applied mostly in the K-12 classrooms, this paper is situated in the context of higher education alongside the efforts to understand and enhance teaching approaches in an online environment.

A review of the sources indicates that online instructors rely in their pedagogy on the general elements of a constructivist paradigm that are found in f2f classrooms, mainly that 1) students are the creators of meaning and knowledge; and 2) classroom practices that foster learning are interactive and student-centered. Online instructors enact these principles through podcasting, Google Doc sharing, and varied and frequent feedback (Bryant \& Bates, 
2015), using wikis, blogs, YouTube videos, and social networking (Reese, 2015). Promoting interaction seems a paramount of constructivist approaches to online education, as students enrolled in online classes stress this element as most important in their learning (Brown, 2012; Heirdsfield, Walker, Tambyah, \& Beutel, 2011; Holzweiss et al, 2014; Lapadat, 2007; Nichols, 2011; Ward, Peters, \& Shelley, 2010). Lapadat (2007), for example, sees "text-based conversation online [as] a new type of discursive interaction" (p. 78) where the instructor and the students collaboratively create discursive devices for building and maintaining community (e.g. greetings, social remarks, help and support, genres and colloquialism, inclusive language) and for achieving discursive coherence (e.g. acknowledging others, marking digression, quoting, posing and answering questions).

Focusing on the interactions among the students that contribute to the online class sense of community Shackelford and Maxwell's (2012) study participants ordered their preferences in the following way: 1) introductions, 2) collaborative group projects, 3) contributing personal experiences, 4) entire class online discussions, and 5) exchanging resources. The question is to what extent these mainly social preferences contribute to learning of the subject matter, or how appropriate the exchange of resource is (e.g. students in a research course recommending to their peers magazine and newspapers articles, blogs, and various websites rather than academic peer-reviewed sources). In their comprehensive review of research on online education published a decade ago, Tallent-Runnels et al. (2006) noted that online interactions could be shallow and lack high-level cognitive engagement.

However, research also points to the encouraging results. When asked about their best online learning experiences, graduate students emphasized critical thinking and problem-solving assignments, research, writing, discussion forums, and videoconferencing (Holzweiss et al., 2014). Bowden (2012) found that asynchronous online discussion forums could facilitate the development of scholarship skills and awareness among graduate students by engaging in the activities such as, recognizing and grappling with task difficulty, asking complex questions, and applying the learned concepts to other fields.

In reviewing research on collaboration as a cornerstone of constructivist education it is impossible not to mention the community of inquiry framework (CoI), which has gained traction with the advancement of online education and has become central in teaching and learning online (Lambert \& Fisher, 2013; Rubin \& Fernandez, 2013; Swan, Garrison, \& Richardson, 2009). Although the CoI framework draws specifically on the writings of John Dewey, we recognize in this research Vygotsky's strand of constructivism as well. In fact, it has been previously suggested that ideas of Vygotsky and Dewey are remarkably similar when describing the kinds of interaction that occur in the classroom (Lyutykh, 2009). Cognitive, social, and teaching presence in online teaching signals to us a rejection of the social-individual dualism in favor of dialectics, a view that both Dewey and Vygotsky espoused. Dewey (1938) captures the spirit of the dialectical transformation in his principle of continuity of experience:

The basic characteristic of habit is that everyday experience enacted and undergone modifies the one who acts and undergoes, while this modification affects, whether we wish it or not, the quality of subsequent experience. (...) The principle of continuity of experience means that every experience both takes up something from those which have gone before and modifies in some way the quality of those which come after. (p. 35)

The CoI epistemology and terminology also have their counterpart in the community of practice framework, rooted in cultural-historical theory (Lave \& Wenger, 1991). However, Vygotsky's dialectical understanding of the human mind and learning offers additional insights, insofar as it recognizes the central role that social relationships and culturally constructed artifacts play in organizing uniquely human forms of thinking (Lantolf, 2004). Therefore, we believe that a closer look at Vygotsky's ideas will yield important implications for online course design and instruction, which we will address shortly.

\subsection{Structure of the Online Qualitative Research Course}

All online classes at the university where we teach are asynchronous, offered on the Blackboard platform every term, and have 10-15 students enrolled. The course has 8 modules. Each module consists of two prompts that become threaded discussions. Readings, syllabus, and assignments are distributed on the Blackboard as well. By the time they are enrolled in this class, all the students have taken several online courses and are fairly comfortable with this format. Qualitative research is a requirement for all doctoral students. The goal of the course is for the students to understand connections between qualitative methods and a variety of theoretical traditions and major types of qualitative designs. As a result of this class, students should be able to develop a basic qualitative research study, analyze and interpret qualitative data, and report of their findings. Through readings, discussion boards, and written assignments we guide the students to become aware of ethical and political dilemmas associated with qualitative research that are aligned but go beyond the university's IRB requirements. Table 1 illustrates class activities and assignments. 
Table 1. Class activities and assignments

\begin{tabular}{lll}
\hline Module & Activities & Assignments \\
\hline 1 & $\begin{array}{l}\text { Blackboard discussion: What is qualitative } \\
\text { research? }\end{array}$ & $\begin{array}{l}\text { Photo-elicitation: Response to an image. } \\
\text { Self-reflection narrative. }\end{array}$ \\
2 & $\begin{array}{l}\text { Blackboard discussion: Qualitative research } \\
\text { designs }\end{array}$ & Study rationale \\
3 & Blackboard discussion: Ethics of research & Bracketing memo/ researchers' positionality \\
4 & Blackboard discussion: Data collection & Interview/observation guide \\
5 & $\begin{array}{l}\text { Blackboard discussion: Data analysis and } \\
\text { interpretation }\end{array}$ & Data collection \\
6 & $\begin{array}{l}\text { Blackboard discussion: Data analysis and } \\
\text { interpretation }\end{array}$ & $\begin{array}{l}\text { Analysis and interpretation of aggregated } \\
\text { self-reflection narratives }\end{array}$ \\
7 & $\begin{array}{l}\text { Blackboard discussion: Validity/ trustworthiness } \\
\text { of qualitative research } \\
\text { Blackboard discussion: Writing and qualitative } \\
\text { research }\end{array}$ & $\begin{array}{l}\text { Final written report: Basic qualitative study on } \\
\text { the topic Purpose of Education }\end{array}$ \\
& &
\end{tabular}

Students work on a shared classroom project entitled, What is the purpose of education from different perspectives? This study is guided by two purposes: to understand the purpose of education from the perspective of the classmates and a participant of choice. Five assignments during the eight modules are building blocks toward the final research report: 1) photo elicitation on students' personal educational experiences, resulting in short self-reflection narratives; 2) write-up of a study rationale (study purpose and questions, sample, design, and a consent letter); 3) a "bracketing memo" that acknowledges and foregrounds students' preconceptions and positionality in relation to the topic and those who they intend to study; 4) an interview or observation guide; and 5) an analysis (via coding) of aggregated individual narratives. The final assignment is an integration that synthesizes the analysis and interpretation of image narratives, interview transcript or observation notes, and student's own voice as a researcher. Through these assignments student merge personal and scholarly ways of writing, which requires them to move flexibly between different meanings and themes generated by research, and highlight commonality and disjunctions in human experiences.

Guided by theoretical insights from reading Lev Vygotsky and scholars who have further developed his ideas, in the next section we propose a design framework, which simultaneously focuses on mediation of high-level engagement and conceptual understanding of qualitative research and on interaction and co-construction of meaning in a qualitative inquiry course.

\section{Vygotskian Framework for Designing an Online Qualitative Research Course}

Cultural-historical theory specifies that both activity and discourse are central features of learning environments. In this section, we discuss four tenets of the theory and demonstrate how they are enacted in a doctoral level online course on qualitative research methods.

\subsection{Scientific Concepts}

The goal of formal education is to mediate internalization of a particular kind of knowledge (Vygotsky, 1986; 1994a), with instructors assisting students in becoming proficient within a sign system (Wertsch, 2007). Research methodology is a kind of cultural knowledge and a sign system that involves a high proportion of abstract, theory-driven concepts, which are not easily accessible in everyday life. To "do research" means not only to understand and operate with the pre-existing knowledge in meaningful ways, but to learn particular ways of generating new knowledge and concepts and relate this new knowledge to what has already been discovered by previous generations. Thus a major focus of course design in qualitative research is to mediate development of scientific concepts (in Vygotskian sense) relevant to qualitative inquiry, to grapple with multiple forms of "evidence," to think critically about issues at hand, as well as to help students become fluent users of this conceptual system. The students who take qualitative research class have already been socialized into the world of research, albeit the quantitative types, and learning what qualitative research is (and what is not), parallels Vygotsky's theorizing of learning a new language. When we learn a new language, we do not "repeat past linguistic developments," but rely on the "native language as a mediator between the world of objects and the new language" 
(Vygotsky, 1986, p. 161). Objects are understood here as entities that facilitate learning and are either externally or internally present (Hoffmann, 2007), such as material objects (e.g. textbooks, digital recorders, printed interview transcripts), signs, representations and knowledge forms (e.g. how is research conceptualized, conducted, and presented; talked and written about; and evaluated).

Elements of the course that illustrate this tenet. Quantitative research is the native research language for most - if not all - students enrolled in the courses we teach. Working in schools, either as teachers or administrators, students' thinking of research inevitably leads to the language of "determining qualitative measures," establishing the "impact of X on Y," or similar phenomena not suitable for a qualitative inquiry. We could spend an entire course untangling the language and epistemology in reworking and rewriting the study questions and purpose, which is unattainable given the short and fast-paced nature of the course. Instead, the students are guided to work on a structured two-layered shared project entitled, What is the Purpose of Education? This "central" research question is broken into two sub-questions: (1) What is the purpose of education from the perspective of graduate students in the online qualitative research course? and (2) What is the purpose of education from the perspective of $\langle\ldots>$ ? To address the second question, the students are asked to interview a participant of their choice.

The direction of this inquiry may seem contrary to some constructivist approaches that advocate for lack of any structure whereupon the students are encouraged to pursue their own inquiry. We contend that while the students cannot unlearn the language of quantitative research, mere reading of examples and getting acquainted with the explicit and implicit discourse of qualitative research are insufficient for the students to develop research questions that could lead to a qualitative inquiry. In the advanced qualitative research course we often witness students falling back to the familiar language of correlation, control groups, and other linguistic expressions that are incongruent with qualitative research. Thus through and with the structured, shared, and guided inquiry, we want the students to learn the new research language, and in this process we mediate their thinking, the topic to which we turn next.

\subsection{Mediation of Thinking}

Lantolf and Thorne (2006) define mediation as a "process through which humans deploy culturally constructed artifacts, concepts, and activities to regulate (i.e. gain voluntary control over and transform) the material world or their own and each other's social and mental activity" (p. 79). When it comes to teaching practice, Vygotsky privileged speech as a means of mediation and internalization (Wertsch, 1985). To think at a higher level is to engage in dialogue, to argue, to agree, to test limits, and to stretch boundaries. A teacher can mediate higher order thinking by co-engaging in thinking with the student: similarly to the read-aloud when learning to read, thinking along and aloud helps the students bring their thinking to a higher level. However, online teaching relies heavily on written speech, which is inherently different from spoken speech in that it requires a certain level of abstraction and proper use of concepts (Vygotsky, 1986). Writing is a form of speech, but without an interlocutor. It is "addressed to an absent or an imaginary person or to no one in particular (...). Written speech is monologous; it is a conversation with a blank sheet of paper. Thus, writing requires a double abstraction: abstraction from the sound of speech and abstraction from the interlocutor" (Vygotsky, 1986, p. 181).

Yet, when mindfully mediated, discourse in and around the written language enables novices to achieve a greater level of understanding and to increase their level of access and participation in the community of practice (Lee \& Smagorinsky, 2000; Rogoff, 1990). Mediation is a relationship between student learning and the resources available in the context of learning (Wittek \& Habib, 2013). Instructors rely on explicit mediation when they overtly introduce signs into classroom activities (e.g. instructing students to draft their interview questions that begin with "How/Why/What does it mean..." rather than "On the scale from 1-5/Do you agree or disagree with the statement...") and implicit meditation, where the signs preexist in the form of natural language and are not intentionally introduced to the task at hand (e.g. instructing students to develop interview questions that would invite the participants to share their experiences) (Wertsch, 2007).

With limitations imposed on the use of speech in the online pedagogy, high quality instructional design becomes crucial. Course content and activities are tools carefully chosen and structured into an activity system (Cole \& Engeström, 1993), capable of mediating students' thinking and action about qualitative research in a particular yet open-ended direction. Since mediated action involves the interaction between the individual and mediating artifacts/tools and signs (Vygotsky, 1978), the content, artifacts, and research tools are embedded within the course in a structured way. Research in traditional classrooms offers important insight: When discovery learning activities are carefully planned and structured, students are led to make particular kinds of interpretations of information (Hickey, 1997; Minstrell \& Stimpson, 1996; White \& Frederiksen, 1998). In an online qualitative research course, students encounter (i.e. discover) certain artifacts (e.g. readings, assignments, prompts) and make use of certain tools (e.g., interview protocols, recording and transcription devices, coding techniques) at certain points of time within structured activities that build on each other and lead to an increased understanding of the qualitative research 
practices. This is the beginning of the researcher's identity formation, or the "social - internalization through sign mediation - restructuring conceptual system - new understanding/consciousness" (Liu \& Matthews, 2005, p. 392).

Elements of the course that illustrate this tenet: Sequencing of readings and assignments leads the students through the intertwined steps of a qualitative inquiry: planning, data collection, data analysis and interpretation, refection, and (re)write-up. Supplementary weekly articles that students read and discuss on the Blackboard are connected to the steps of their inquiry. Rather than working throughout the term on one "big assignment" at their own pace, students arrive at their own paper by following a series of small-scale assignments that are shared and discussed on discussion board prior to submission. Going back to the example of formulating interview questions, the implicit form of mediation is students' first attempt at this assignment, which represents a new cultural tool. Students often confuse study guiding questions with interview questions or come up with the list of questions suitable for a survey. An online discussion that follows involves an exchange between an instructor and students (providing explicit feedback) and students and students (comparing and borrowing ideas). The mediation therefore becomes explicit, reflecting the broad agreement of "how things are done in the field."

\subsection{Cognitive Apprenticeship}

In online qualitative research classes the nature of student-teacher relationship and interaction is one of the "cognitive apprenticeship" (Rogoff, 1990), which centers on higher order thinking-along by the teacher and the students in the context of meaningful activity. Duschl and Osborne (2002) described two kinds of discourse in the classrooms: dialogic and monologic. Dialogic discourse "requires the opportunity to consider plural theoretical accounts and the opportunity to construct and evaluate arguments" (p. 52). It is through a dialogue that the interlocutors pose questions of each other that require making an explicit connection between previously internalized scientific concepts and those that are currently being mediated and internalized.

This is accomplished through a process of mutual adaptation between each student and the teacher, a kind of give-and-take in which the participants learn from each other. A teacher needs to focus a student on concepts of qualitative research, through calls for elaboration on everyday experiences and higher order thinking about them in more abstract terms (Vygotsky, 1994a). Importantly, this higher order thinking happens on both sides, prompting both parties to stretch their minds: the teacher engages in higher order thinking as he or she models and mediates learning; the student is cognitively and affectively engaged in thinking along with the teacher.

Thinking is not the product of an action but the action itself, considered at the moment of its performance, just as walking, for example, is the mode of action of the legs, the "product" of which, it transpires, is the space walked (Ilyenkov, 1977). Consequently, an online qualitative research course is thinking and process centered rather than outcome and product driven insofar as a higher value is assigned to the quality of "thinking along and aloud" and the re-writing /revising as a reflection of such thinking, rather than to the absolute quality of the final product, which could remain in an inchoate state. We agree with Wittek \& Habib (2013) who argued that,

students cannot make sense of anything without a language or other sorts of representational systems such as the academic cultures that exist within the various institutions where they receive their education (...). Academic cultures are made available for students by core mediational means, which may vary according to the disciplinary and professional fields covered by the studies. The student must negotiate his/her own professional learning trajectories through dialogue, partly overt, partly internal. (p. 276)

Elements of the course that illustrate this tenet. The involvement of the instructor on the discussion board is extensive. Discussion board is treated as a "try it out" space where students post their initial ideas and get critique and feedback first and foremost from the instructor. Assignments mirror the discussion in the way that the students first communicate their ideas and have an opportunity to revise their assignments before submitting them for grading. Furthermore, as instructors, we do not take for granted that students will inevitably make connections in the pedagogical content artificially divided into "content" and "research" courses in their doctoral studies.

For instance, prior to qualitative research, students take a class on different paradigms in scientific research. And although they all have encountered the buzzword "paradigm shift" at their workplace, the students struggle with understanding of a paradigm as the "general organization of the descriptive and explanatory principles" (how different methodologies emanate from different paradigms) rather than "concrete description of specific phenomena" (how to use observational notes when attempting to describe behavior) (Liu \& Matthews, 2005). While we are excited to witness moments of realization in the classroom, we have become explicit over the years in establishing our online teaching presence (Garrison, 2007), not wishing to leave students to their own devices, since this could lead to disengagement and a sense of disconnection. We have observed that adding pre-recorded video material to the asynchronous course did not enhance the course discussion nor the quality of the written papers; therefore, we organize individual Skype sessions that students describe as helpful. 


\subsection{Community of Practice}

Qualitative research is a professional practice, guided by methods developed by a scholarly community. Learning of these practices never happens in a vacuum; rather, it occurs in interaction with a more experienced other in the context of inquiry and/or practice in a particular socio-historical context. Such interaction requires the teacher and the learner to co-engage in continuous and extensive dialogue as they co-participate in doing an authentic task in a community of practice (Rogoff, 1990; Lave \& Wenger, 1991). Students, who are also professionals (e.g., teachers, administrators, leaders) bring to the classroom their own sets of professional practices, which are not always easily compatible with practices and beliefs shared by the qualitative research community. It is therefore desired to preserve inherent dialectical sensitivity to the intrapersonal dimensions of human activity and the normalizing pressures of socially expected forms of behavior (in Thorne, 2004). In the context of online qualitative inquiry, the community of practice in the classroom becomes a unique space where students' intrapersonal practices are shared and (re)negotiated interpersonally as they come into contact with professional practices typically employed in qualitative inquiry.

Discussion boards in online research methods classes are a sociocultural community where students dialogue with an instructor - a "more experienced other" - in research-focused activities with a goal to internalize knowledge and ways of doing research. A shared discussion space within the community of practice enables students to develop and competently use an apparatus of relevant concepts, i.e. a more sophisticated way of thinking about the reality(ies).

The ways this dialogue unfolds on the online teaching platform illustrates well the ambiguities about constructivist teaching and learning online. As instructors, we formulate discussion topics; therefore, we decide what to emphasize, or at least initially, where to direct students' responses. We want to stress certain pedagogical and methodological moments, but we also see a discussion board as a space to further hone in on the tropes and forms of academic writing. As school professionals, many of our students are accustomed to writing technical reports and office "memos," whose language often stands in a stark opposition to scholarly writing. Without an instructor's teaching presence, Blackboard discussion threads could turn into "everyday talk," or sharing of personal experiences. We certainly recognize the importance of friendly remarks and personal anecdotes, as they are an interactive glue, without which the discussion board appears lifeless. However, the goal of the course is to introduce the students to the expected practice within an academic community: questioning, critical examination, and negotiation of meaning (Daniels, 2007).

Community of inquiry and practice also engages the instructors to be attuned to the different group dynamics that always emerge despite the fact that we are visible to each other through text only. Certain ideas and topics that create an excitement or challenge for one group may be barely noticed by the other. A question may arise that requires a revised or additional list of readings.

Elements of the course that illustrate this tenet. In setting up the course, the feedback and critique of ideas in the shared space of the discussion forum, as opposed to solely individualized feedback via grading and emails, are stated as a course requirement. Each students is required to create one post and respond to two classmates. One-liners, such as "I agree!" or "I found the readings interesting" are not seen as adequate posts. Students are asked to address a point, make a claim, or formulate an argument citing scholarly sources and engage in a written conversation with their classmates. A critique of this practice as compulsory participation has it that by making it a requirement, the interaction become a passive and imposed knowledge rather than an example of constructivism (Gulati, 2008).

We argue that students learn only when their current views and knowledge are challenged and synthesized through their interaction with others (Vygotsky, 1978), and this interaction is shared among the participants of the course emulating a research community of practice. Online posts could certainly read as an echo chamber, particularly when all the students enrolled in the class work in the same area or school district, which could lead to airing the same (local) occurrences. It is also a social space where research anxieties are in the open: by positioning themselves as novice researchers, the students are encouraged to think aloud about their emerging research skills and how they may be realized in the dissertation research. Vygotsky scholars argue that through such "mutual appropriation, ideas and concepts migrate throughout the community." Also, "over time the community of learners adopts a common voice, a common knowledge base, and a shared system of meaning, beliefs, and activity" (Daniels, 2007, p. 327).

\section{Conclusions}

The transcendent goal in teaching qualitative research is to engage the students in multi-perspective inquiry as a way to explore underlying assumptions, uniqueness, and complexity of human experiences (Henderson, 2000). Since online teaching and learning are educational mainstream rather than fad, many instructors of qualitative research methods face a dilemma of how to convey a complex process of engaging in qualitative inquiry, including its technical aspects, without reducing teaching to linear sets of prescriptions. Teaching and learning are two sides of a 
dialectical process that must involve interactions entailing higher order thinking between the instructor and the students in the context of meaningful activity (Vygotsky, 1994). This paper continues efforts to re-conceptualize pedagogies in qualitative courses and offers course design ideas to help doctoral candidates bring continued scholarship into their professional practice. Sharing such pedagogical ideas remains an important contribution to the field of professional preparation of educational leaders and administrators.

\section{References}

Allen, I. E., \& Seaman, J. (2014). Grade change: Tracking online education in the United States. Babson Survey Research Group and Quahog Research Group, LLC. Retrieved from http://www.onlinelearningsurvey.com/reports/gradechange.pdf

Booker, K. (2009). Shifting priorities: Reflections on teaching qualitative research methods. The Qualitative Report, 14(3), 389-394.

Bowden, R. (2012). Online graduate education: Developing scholars through asynchronous discussion. International Journal of Teaching and Learning in Higher Education, 24(1), 52-64.

Breuer, F., \& Schreier, M. (2007). Issues in learning about and teaching qualitative research methods and methodology in the social sciences [46 paragraphs]. Forum Qualitative Sozialforschung / Forum: Qualitative Social Research, 8(1), Art. 30. Retrieved from http://nbn-resolving.de/urn:nbn:de:0114-fqs0701307

Brown, J.L.M. (2012). Online learning: A comparison of web-based and land-based courses. The Quarterly Review of Distance Education, 13(1), 39-42.

Bryant, J., \& Bates, A.J. (2015). Creating a constructivist online instructional environment. TechTends, 59(2), 17-22. https://doi.org/10.1007/s11528-015-0834-1

Cole, M., \& Engestrom, Y. (1993). A cultural historical approach to distributed cognition. In G. Salomon (Ed.), Distributed cognitions. Cambridge. MA: Cambridge University Press.

Cox, R. D. (2012). Teaching qualitative research to practitioner-researchers. Theory into Practice, 51, 129-136. https://doi.org/10.1080/00405841.2012.662868

Creamer, E.G., Ghoston, M. R., Drape, T., Ruff, C., \& Mukuni, J. (2012). Using popular media and a collaborative approach to teaching Grounded Theory research methods. International Journal of Teaching and Learning in Higher Education, 24(3), 415-420.

Creswell, J.W. (2012). Qualitative inquiry and research design: Choosing among five approaches ( $3^{\text {rd }}$ ed.). Thousand Oaks, CA: Sage.

Daniels, H. (2007). Pedagogy. In H. Daniels, M. Cole, \& J. V. Wertsch (Eds.), The Cambridge companion to Vygotsky (pp. 307-331). New York: Cambridge University Press. https://doi.org/10.1017/CCOL0521831040.013

Denzin, N.K., \& Lincoln, Y.S. (2013a). Collecting and interpreting qualitative materials (4th ed.). Thousand Oaks, CA: Sage.

Denzin, N.K., \& Lincoln, Y.S. (2013b). Strategies of qualitative inquiry $\left(4^{\text {th }}\right.$ ed.). Thousand Oaks, CA: Sage.

Dewey, J. (1938). Experience and education. New York: MacMillan.

Duschl, R., \& Osborne, J. (2002). Argumentation and discourse processes in science education. Studies in Science Education, 38, 39-72. https://doi.org/10.1080/03057260208560187

Garrison, D. R. (2007). Online community of inquiry review: Social, cognitive, and teaching presence issues. Journal of Asynchronous Learning Networks, 11(1), 61-72.

Glesne, C. (2013). Becoming qualitative researchers: An introduction ( $5^{\text {th }}$ ed.). Boston: Pearce.

Gulati, S. (2008). Compulsory participation in online discussions: Is this constructivism or normalisation of learning? Innovations in Education and Teaching International, 45(2), 183-192. https://doi.org/10.1080/14703290801950427

Heirdsfield, A., Walker, S., Tambyah, M., \& Beutel, D. (2011). Blackboard as an online learning environment: What do teacher education students and staff think? Australian Journal of Teacher Education, 36(7), 1-16. https://doi.org/10.14221/ajte.2011v36n7.4

Henderson, J. (2000). Reflective teaching: Professional artistry through inquiry $\left(3^{\text {rd }}\right.$ ed). Columbus, OH: Merrill/Prentice Hall. 
Hickey, D. T. (1997). Motivation and contemporary socio-constructivist instructional perspectives. Educational Psychologist, 32, 175-193. https://doi.org/10.1207/s15326985ep3203_3

Hoffmann, M.C. (2007). Learning from people, things, and signs. Studies in Philosophy and Education, 26(3), 185-204. https://doi.org/10.1007/s11217-007-9027-5

Holzweiss, P. C., Joyner, S. A., Fuller, M.B., Henderson, S., \& Young, R. (2014). Online graduate students' perceptions of best learning experiences. Distance Education, 35(3), 311-323. https://doi.org/10.1080/01587919.2015.955262

Humble, A., \& Sharp, E. (2012). Shared journaling as peer support in teaching qualitative research methods. The Qualitative Report, 17, article 96, 1-19. Retrieved from http://www.nova.edu/ssss/QR/QR17/humble.pdf

Hunter, C. A., Hinderliter Ortloff, D., \& Winkle-Wagner, R. (2014). Out of our comfort zones: Reflections about teaching qualitative research at a distance. The Qualitative Report, 19(T\&L 3), 1-25.

Ilyenkov, E. (1977). Dialectical logic: Essays on its history and theory. Moscow: Progress Press.

Johns, M.D., Chen, S.S., \& Hall, G.J. (2004). Online social research: Methods, issues, ethnics. New York: Peter Lang.

Kentnor, H. E. (2015). Distance education and the evolution of online learning in the United States. Curriculum and Teaching Dialogue, 17(1/2), 21-34.

Lambert, J. L., \& Fisher. J. L. (2013). Community of Inquiry framework: Establishing community in an online course. Journal of Interactive Online Learning, 12(1), 1-16. Retrieved from http://www.ncolr.org/jiol/issues/pdf/12.1.1.pdf

Lantolf, J. (2004). Sociocultural theory and second and foreign language learning: An overview of sociocultural theory. In K.van Esch \& O. St. John (Eds.), New insights into foreign language learning and teaching (pp. 13-34). Frankfurt, Germany: Peter Lang.

Lantolf, J. P., \& Thorne, S. L. (2006). Sociocultural theory and the genesis of second language development. New York: Oxford University Press.

Lapadat, J. C. (2007). Discourse devices used to establish community, increase coherence, and negotiate agreement in an online university course. Journal of Distance Education, 21(3), 59-92.

Lave, J., \& Wenger, E. (1991). Situated learning: Legitimate peripheral participation. Cambridge, UK: Cambridge University Press. https://doi.org/10.1017/CBO9780511815355

Lee, C. D., \& Smagorinsky, P. (Eds.) (2000). Vygotskian perspectives on literacy research: Constructing meaning through collaborative inquiry. New York: Cambridge University Press.

Liu, C. H., \& Matthews, R. (2005). Vygotsky's philosophy: Constructivism and its criticisms examined. International Education Journal, 6(3), 386-399.

Lyutykh, E. (2009). Practicing critical thinking in an educational psychology classroom: Reflections from a cultural-historical perspective. Journal of Educational Studies, 45(4), 377-391.

Marshall, C., \& Rossman, G. B. (2016). Designing qualitative research $\left(6^{\text {th }}\right.$ ed.). Thousand Oaks, CA: Sage.

Maxwell, J. A. (2012). Qualitative research design: An interactive approach ( $3^{\text {rd }}$ ed.). Thousand Oaks, CA: Sage.

Merriam, S. B. (2009). Qualitative research: A guide to design and implementation (3 ${ }^{\text {rd }}$ ed.). San Francisco, CA: Jossey-Bass.

Minstrell, J., \& Stimpson, V. (1996). A classroom environment for learning: Guiding students' reconstruction of understanding and reasoning. In L. Schauble \& R. Glaser (Eds.), Innovations in learning: New environments for education (pp. 175-202). Mahwah, NJ: Erlbaum.

Morrison-Saunders, A., \& Hobson, J. (2013). Being subject-centered: A philosophy of teaching and implications for higher education. Issues in Educational Research, 23(2), 212-226.

Mulvihill, T.M., Swaminathan, R., \& Bailey, L.C. (2015). Catching the "tail/tale" of teaching qualitative inquiry to novice researchers. The Qualitative Report, 20(9), 1490-1498. Retrieved from: http://nsuworks.nova.edu/tqr/vol20/iss9/13

Nichols, J. (2011). Comparing educational leadership course and professor evaluations in an on-line and traditional instructional formats: What are the students saying? College Student Journal, 45(4), 862-868. 
Onwuegbuzie, A., Leech, N.L., Slate, J.R., Stark, M., Sharma, B., Frels, R., \& Combs, J.P. (2012). An exemplar for teaching and learning qualitative research. The Qualitative Report, 17(1), 16-77. Retrieved from http://www.nova.edu/ssss/QR/QR17-1/onwuegbuzie.pdf

Ortagus, J. C., \& Stedrak, L. J. (2013). Online education and contingent faculty: An exploratory analysis of issues and challenges for higher education administrators. Educational Considerations, 40(3), $30-33$. https://doi.org/10.4148/0146-9282.1096

Popkewitz, T. S. (2001). Dewey and Vygotsky: Ideas in historical spaces. In T.S. Popkewitz, B.M. Franklin, and M.A. Pereyra (Eds.), Cultural history and education: Critical essays on knowledge and schooling (pp. 313-349). New York: Routledge.

Poynter, R. (2010). The handbook of online and social media research: Tools and techniques for market researchers. West Sussex, UK: Wiley \& Sons.

Reese, S. (2015). Online learning environments in higher education: Connectivism vs. dissociation. Education and Information Technologies, 20(3), 579-588. https://doi.org/10.1007/s10639-013-9303-7

Rogoff, B. (1990). Apprenticeship in thinking. New York: Oxford University Press.

Rubin, B., \& Fernandes, R. (2013). Measuring the community in online classes. Journal of Asynchronous Learning Networks, 17(3), 115-136. https://doi.org/10.24059/olj.v17i3.344

Shackelford, J.L., \& Maxwell, M. (2012). Sense of community in online graduate education: Contribution of leaner to learner interaction. International Review of Research in Open and Distance Learning, 13(4), 228-248. https://doi.org/10.19173/irrodl.v13i4.1339

Swan, K., Garrison, D.R., \& Richardson, J.C. (2009). A constructivist approach to online learning: The Community of Inquiry framework. In C. R. Payne (Ed.), Information technology and constructivism in higher education (pp. 43-57). Hershey, PA: Information Science Reference. https://doi.org/10.4018/978-1-60566-654-9.ch004

Tallent-Runnels, M.K., Thomas, J.A., Lan, W.Y., Cooper, S., Ahern, T.C., Shaw, S.M., \& Liu, X. (2006). Teaching courses online: A review of the research. Review of Educational Research, 76(1), 93-135. https://doi.org/10.3102/00346543076001093

Thorne, S. (2004). Cultural historical activity theory and the object of innovation. In O. St. John \& K. van Esch (Eds.), New insights into foreign language learning and teaching (pp. 51-70). Frankfurt, Germany: Peter Lang.

U.S. Department of Education (2014). Web tables: Enrollment in distance education course, by state: Fall 2012. Retrieved from http://nces.ed.gov/pubs2014/2014023.pdf

Vygotsky, L. (1978). Mind in society. Cambridge, MA: Harvard University Press.

Vygotsky, L. (1986). Thought and language (A. Kozulin, Ed.). Cambridge, MA: MIT Press.

Vygotsky, L. (1994). The development of thinking and concept formation in adolescence. In R. Van Der Veer \& J. Valsiner (Eds.), The Vygosky reader (pp. 185-265). Cambridge MA: Blackwell.

Waite, D. (2014). Teaching the unteachable: Some issues of qualitative research pedagogy. Qualitative Inquiry, 20(3), 267-281. https://doi.org/10.1177/1077800413489532

Ward, M.E., Peters, G., \& Shelley, K. (2010). Student and faculty perceptions of the quality of online learning experiences. International Review of Research in Open and Distance Learning, 11(3). https://doi.org/10.19173/irrodl.v11i3.867

Wertsch, J. V. (1985). Vygotsky and the social formation of mind. Cambridge, MA: Harvard University Press.

Wertsch, J. V. (2007). Mediation. In H. Daniels, M. Cole, \& J. V. Wertsch, The Cambridge companion to Vygotsky (pp. 178-192). New York: Cambridge University Press. https://doi.org/10.1017/CCOL0521831040.008

White, B., \& Frederiksen, J. (1998). Inquiry, modeling, and metacognition: Making science accessible to all students. Cognition and Instruction, 16(1), 3-118. https://doi.org/10.1207/s1532690xci1601_2

Wittek, L., \& Habib, L. (2013). Quality teaching and learning as practice within different disciplinary discourses. International Journal of Teaching and Learning in Higher Education, 25(3), 275-287. 